\title{
Evaluation of Portal Venous Flow as a Non-invasive Method for Diagnosing Liver Fibrosis in Patients with Chronic Hepatitis $B$
}

\author{
Kronik Hepatit B'li Hastalarda Karaciğer Fibrozunun Teșhis Edilmesi İçin Non-invaziv \\ Bir Yöntem Olarak Portal Venöz Debinin Değerlendirilmesi
}

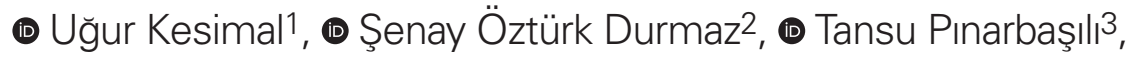 \\ ${ }^{1}$ Recep Tayyip Erdoğan University Training and Research Hospital, Clinic of Radiology, Rize, Turkey \\ 2Kepez State Hospital, Clinic of Infectious Diseases and Clinical Microbiology, Antalya, Turkey \\ ${ }^{3}$ Kepez State Hospital, Clinic of Radiology, Antalya, Turkey
}

\begin{abstract}
Objectives: This study aimed to evaluate the relationship between portal venous flow (PVF), which could be measured non-invasively with Doppler ultrasound, and the degree of fibrosis obtained by biopsy in patients with chronic hepatitis (CHB).

Materials and Methods: The study included 133 patients with CHB. During the Doppler evaluation, PVF was calculated in addition to routine measurements. The patients were divided into two groups according to the degree of fibrosis based on the biopsy results: F0 and F1 (first group) and F2, F3 and F4 (second group). The Doppler ultrasound findings obtained from all patients were compared with the pathology results.

Results: The mean PVF was measured as $688.38 \pm 608.2 \mathrm{~mL} /$ minute. An inverse correlation was detected between PVF and liver fibrosis degree ( $p<0.0001$, Spearman's correlation coefficient 0.47 ). In the receiver-operating characteristic analysis, the area under the curve was $71.1 \%$ (95\% confidence interval: 55.6\%-83.6\%). The cut-off value for PVF was calculated as $480 \mathrm{~mL} /$ minute, at which it had a sensitivity of $57.8 \%$ and specificity of $100 \%$.

Conclusion: We considered that the decrease we showed in PVF in our study could be used as a non-invasive evaluation method in the differentiation of mild and significant fibrosis in non-cirrhotic patients.
\end{abstract}

Keywords: Chronic hepatitis B, Doppler ultrasonography, noninvasive fibrosis test

\section{ÖZ}

Amaç: Bu çalışmada, kronik hepatit B (KHB) hastalarında noninvaziv olarak Doppler ultrason ile ölçülebilen portal venöz akım (PVA) ve biyopsi ile elde edilen fibrozis derecesi arasındaki ilişkinin değerlendirilmesi amaçlanmıştır.

Gereç ve Yöntemler: Çalışmaya KHB hastası 133 hasta dahil edildi. Doppler değerlendirmesi sırasında rutin ölçümlere ek olarak PVA hesaplandı. Hastalar biyopsi sonuçlarına göre fibrozisin derecesine göre F0 ve F1 (birinci grup) ve F2, F3 ve F4 (ikinci grup) olmak üzere iki gruba ayrıldı. Tüm hastalardan elde edilen Doppler ultrason bulguları patoloji sonuçları ile karşılaştırıldı.

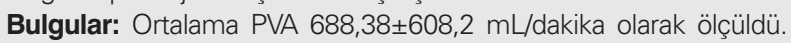
PVA ile karaciğer fibrozisi derecesi arasında ters korelasyon saptandı $(p<0,0001$, Spearman korelasyon katsayısı 0,47). ROC analizinde eğrinin altında kalan alan \%71,1 idi (\%95 güven aralı̆ı: \%55,6\%83,6). PVA için cut-off değeri $480 \mathrm{~mL} /$ dakika olarak hesaplandı ve bu değerde duyarlıı̆ı \%57,8 ve özgüllüğü \%100 idi.

Sonuç: Çalışmamızda PVA'da gösterdiğimiz azalmanın, sirotik olmayan hastalarda hafif ve anlamlı fibrozisin ayrımında non-invaziv bir değerlendirme yöntemi olarak kullanılabileceğini düşündük. Anahtar Kelimeler: Kronik hepatit B, Doppler ultrasonografi, noninvaziv fibrozis testi

Kesimal U, Öztürk Durmaz Ş, Pınarbaşılı T. Evaluation of Portal Venous Flow as a Non-invasive Method for Diagnosing Liver Fibrosis in Patients with Chronic Hepatitis B. Viral Hepat J. 2021;27:93-97.

Address for Correspondence: Uğur Kesimal MD, Recep Tayyip Erdoğan University Training and Research Hospital, Clinic of Radiology, Rize, Turkey Phone: +90 5426188607 E-mail: ugur_kesima/@hotmail.com ORCID ID: orcid.org/0000-0002-7994-5482 Received: 21.02.2020 Accepted: 20.06.2021

(c) Copyright 2021 by Viral Hepatitis Society / Viral Hepatitis Journal published by Galenos Publishing House. 


\section{Introduction}

Clinical manifestations due to hepatitis B virus (HBV) emerge as an important global health problem, and the most common of these conditions is chronic hepatitis $\mathrm{B}(\mathrm{CHB})$. In CHB patients, the treatment decision is made according to HBV-DNA and alanine aminotransferase (ALT) levels, and the degree of necroinflammation and degree of fibrosis in the liver biopsy. A liver biopsy is the gold standard in evaluating liver fibrosis; however, due to complications, such as pain, bleeding, and pneumothorax, variable pathology interpretations, and these risks being repeated in each biopsy required, researchers have begun to seek non-invasive tests for detecting fibrosis $(1,2,3,4,5,6)$.

Doppler ultrasonography (US) is a widely accepted imaging method due to its easy accessibility, non-invasiveness, reproducibility when desired, and low cost, despite possible errors in the evaluation of chronic hepatitis patients and differences between practitioners. A Doppler US assessment is widely used in the follow-up of chronic hepatitis patients to obtain useful information about hepatic parenchymal morphology and hemodynamic changes $(7,8)$.

Although there are trials and studies on the use of noninvasive fibrosis markers in patients with chronic hepatitis $\mathrm{C}$, the data on the use of these markers in $\mathrm{CHB}$ patients remain limited $(9,10,11,12,13)$. This study aimed to determine whether portal venous flow (PVF) detected by Doppler US was related to the degree of fibrosis obtained from percutaneous biopsies in $\mathrm{CHB}$ patients.

\section{Materials and Methods}

This study was conducted with the approval of the Clinical Research Ethics Committee of our university (approval number: 9/15, date: 18.06.2020). A prospective diagnostic accuracy study was conducted in our hospital between December 2018 and December 2019, involving 133 CHB patients. All patients provided written informed consent.

The inclusion criteria were being aged 18-70 years and having a diagnosis of chronic hepatitis serologically related to HBV according to the biopsy result. Patients that were hepatotoxic and those using drugs that could cause hemodynamic changes in liver Doppler flow were excluded from the study. Further excluded were patients with coagulation disorders or heart failure, and pregnant women.

Automatic pistol needle biopsies $(16 \mathrm{~W} \times 15 \mathrm{~cm}$, ESTACOR to, GEOTEK Medical, Ankara, Turkey) were performed through intercostal access under ultrasound guidance in the interventional radiology unit. The patients' demographic characteristics, ALT and HBV-DNA levels, platelet counts, and pathology reports were obtained from the electronic hospital files and by screening epicrises.

In order to clinically evaluate the chronic hepatitis stage and correlate it with the Doppler data, the patients were divided into two groups according to the degree of fibrosis: the first group that did not have significant fibrosis ( $F 0$ and $F 1)(n=42)$ and the second group with a high degree of fibrosis (F2, F3 and F4) (n=91). In liver biopsies, the histopathological evaluation was made according to the METAVIR scoring system.

All 133 patients were examined with Doppler and grayscale US using a 2-5 MHz frequency convex ultrasound probe (Canon
Aplio 500, Canon Medical System Corporation, Tokyo, Japan). The patients underwent the ultrasound evaluation in the supine position in the morning after fasting for 10 to 12 hours. All ultrasounds were performed by the same radiologist. All segments of the liver were examined with grayscale and Doppler US. Patients with structural abnormalities in hepatic vascular structures and focal parenchymal lesions were excluded from further analysis. Ultrasound parameters were obtained within one week after the biopsy procedure. Doppler portal vein parameters were obtained during apnea at the beginning of inspiration to avoid changes caused by deep inspiration. The smallest possible pulse repetition frequency setting was chosen to minimize measurement errors. Care was taken to ensure that the angle between the ultrasound beam and the vein to be examined was always below 60. Portal vein measurements were performed at the inferior vena cava level with the least variability between practitioners, using an intercostal and subcostal approach. To calculate PVF, the mean portal venous velocity and cross-sectional area were measured in the transverse plane. PVF was automatically obtained from these values as a function of the Doppler device.

\section{Statistical Analysis}

Statistical analyses were performed using the SPSS, version 15 (SPSS Inc, Chicago, IL). The Kolmogorov-Smirnov test was used to evaluate the conformance of continuous variables to normal distribution. Descriptive statistics were expressed as mean, standard deviation, frequency and percentages. During statistical analysis, the correlation between Spearman's rank correlation coefficient and data was evaluated. A p-value of less than 0.05 was considered statistically significant.

\section{Results}

Of the 133 patients included in the study, 88 were men and 45 were women. The mean age of all patients was calculated as $41.82 \pm 12.48$ years. ALT levels in seven men and four women were above the cut-off value of $35 \mathrm{IU} / \mathrm{L}$. The fibrosis value indicated F2 to F4 level of fibrosis in 91 patients. In 42 patients, the fibrosis value was reported as F0 or F1; i.e., low degree of fibrosis. Portal and splenic vein diameters were calculated as $10.56 \pm 1.64$ and $4.7 \pm 1.64 \mathrm{~mm}$, respectively. The mean PVF was measured as $688.38 \pm 608.2 \mathrm{~mL} / \mathrm{min}$. The descriptive, laboratory and pathology findings of the sample are shown in Table 1, and portosystemic hemodynamic parameters in Table 2.

There was no statistically significant correlation between the histological activity index and hemodynamic parameters of the patients. In the correlation evaluation between the PVF and liver fibrosis degree of the patients, a statistically significant

\begin{tabular}{|l|l|l|}
\hline \multicolumn{3}{|l|}{ Table 1. Descriptive, laboratory and pathology results } \\
\hline & Mean & $\begin{array}{l}\text { Standard } \\
\text { deviation }\end{array}$ \\
\hline Age & 41.82 & 12.49 \\
\hline Platelet count $\left(10^{3} / \mu \mathrm{L}\right)$ & 218.91 & 58.06 \\
\hline Alanine aminotransferase $(\mathrm{U} / \mathrm{L})$ & 30.56 & 15.15 \\
\hline Fibrosis degree & 2.22 & 0.74 \\
\hline Histological activity index & 7.67 & 2.49 \\
\hline
\end{tabular}


inverse relationship was found $(p<0.0001$, Spearman's correlation coefficient: 0.47). Apart from this, there was no correlation between the portosystemic hemodynamic parameters and the degree of fibrosis. The p-values of the correlation analysis between the pathological and portosystemic hemodynamic data of the patients are shown in Table 3. We used the ROC curve to determine the PVF cut-off value in the diagnosis of significant liver fibrosis in $\mathrm{CHB}$ patients. In this analysis, the area under the curve was $71.1 \%(95 \%$ confidence interval: 55.6\%-83.6\%). The cut-off value for PVF was calculated as $480 \mathrm{~mL} / \mathrm{min}$, at which this parameter had $57.8 \%$ sensitivity and $100 \%$ specificity (Figure 1).

\section{Discussion}

HBV infection is one of the leading causes of chronic liver disease worldwide (14). The aim of HBV treatment is to prevent HBV replication, decrease necroinflammatory activity, and stop the progression of fibrosis. The evaluation of the degree of liver fibrosis in HBV patients plays a key role for better clinical management since the treatment decision is usually made according to the degree of necroinflammation (15). It is also very important to

\begin{tabular}{|l|l|l|}
\hline \multicolumn{2}{|l|}{ Table 2. Portosystemic hemodynamic results } \\
\hline & Mean & $\begin{array}{l}\text { Standard } \\
\text { deviation }\end{array}$ \\
\hline Portal vein diameter $(\mathrm{mm})$ & 10.56 & 1.64 \\
\hline Portal venous flow $(\mathrm{mL} / \mathrm{minute})$ & 688.38 & 608.21 \\
\hline Splenic vein diameter $(\mathrm{mm})$ & 4.70 & 1.64 \\
\hline Spleen size & 102.91 & 16.77 \\
\hline
\end{tabular}

Table 3. P-values obtained from Spearman's correlation test

\begin{tabular}{|l|l|l|}
\hline & Fibrosis & $\begin{array}{l}\text { Histological } \\
\text { activity index }\end{array}$ \\
\hline Portal vein diameter & 0.465 & 0.620 \\
\hline Portal venous flow & $0.003^{*}$ & 0.922 \\
\hline Splenic vein diameter & 0.746 & 0.212 \\
\hline Spleen size & 0.627 & 0.324 \\
\hline
\end{tabular}

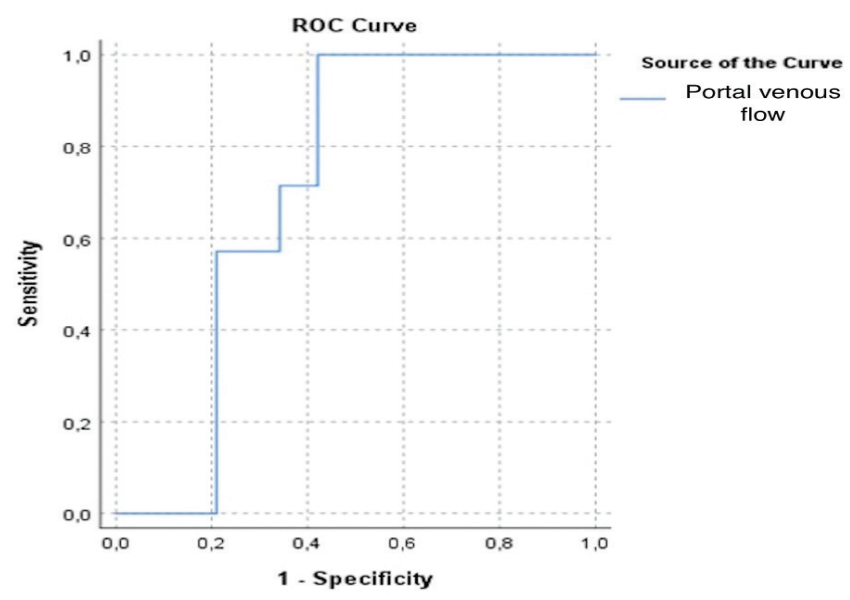

Figure 1. ROC curve for portal venous flow ROC: Receiver-operating characteristic evaluate the early stages of liver fibrosis, especially in patients with chronic viral hepatitis because the prognosis is mainly determined by the degree of fibrosis (16). Despite its contraindications and complications, a liver biopsy is still considered as the gold standard for defining the degree of liver fibrosis and guiding treatment (17).

Many new laboratory and imaging methods are being investigated for a non-invasive evaluation of liver fibrosis (17). Doppler US is a non-invasive method for evaluating liver hemodynamics and can be easily performed at the same time as routine upper abdominal US. However, due to limited data and conflicting results $(18,19,20,21)$, the clinical role of Doppler measurements in evaluating non-cirrhotic liver disease remains controversial $(18,19,22,23,24)$. In this regard, Doppler US methods have been the subject of several publications $(18,24,25)$. These methods include the measurement of maximum and minimum velocities of the portal vein, PVF, congestive index, and portal venous index (15).

In the pathology of liver diseases within the range of chronic hepatitis to decompensated cirrhosis, there are various changes, such as hepatocellular inflammation, necrosis, development of regenerative nodules, collagen deposition, and lobule reconstruction. These pathological changes may result be gradual, with increasing intensity at each stage, with the increase in resistance to the portal vein, a decrease in its velocity, and an enlargement of its diameter. The enlargement of the portal vein diameter can counteract the reduction in portal vein velocity, and thus a certain degree of stability can be achieved in PVF to maintain hepatic perfusion (26).

Modifications occur in the usual architecture of the liver associated with sinusoidal vascular impairment due to HBV infection. As a result, various degrees of liver inflammation and fibrosis are known to occur. These changes can theoretically lead to alterations in intrahepatic and extrahepatic vascular impedance, which can be detected by the Doppler examination of the portal vein, hepatic vein, and hepatic artery. Several Doppler ultrasound parameters have been investigated to identify hemodynamic changes in the liver, but there is still no consensus on which option is best for determining the degree of liver fibrosis $(27,28,29)$.

In a study by Su et al. (26), a statistically significant difference was found between the control group and chronic hepatitis patients, as well as between chronic hepatitis and compensated cirrhotic patients in terms of the portal vein diameter and velocity, but no difference was observed in terms of PVF Similarly, Zheng et al. (30), evaluating cirrhotic patients, reported that the degree of fibrosis was associated with the portal vein diameter and velocity, splenic vein diameter, and spleen size; however, they did not detect any relationship between PVF and fibrosis. The most important difference between these previous studies and our study is that we did not include cirrhotic patients in our sample. In other studies in the literature that did not evaluate cirrhotic patients, Rocha et al. (15) and Bernatik et al. (24) showed no relationship between the degree of fibrosis and portal vein velocity and flow, but the sample sizes of both studies were much lower than the previously mentioned works. In contrast, we found a statistically significant negative correlation between PVF and liver fibrosis in our study. We calculated the cut-off value of PVF as $480 \mathrm{~mL} / \mathrm{min}$ in differentiating between patients with mild and significant fibrosis. The extent to which and the order in which fibrosis, inflammation, and steatosis 
can alter arterial and venous hepatic vascular patterns before cirrhosis remain controversial (15). Therefore, we consider that this decrease in PVF, which we detected in our sample that did not include cirrhotic patients, can be used as a non-invasive evaluation method in the differentiation between mild and significant fibrosis. However, this recommendation should be supported by studies conducted with larger case series. Nevertheless, none of the threshold parameters obtained by non-invasive laboratory or imaging methods has good diagnostic performance. In the literature, it has been stated that using at least two of these noninvasive laboratory tests simultaneously are useful in the evaluation and follow-up of the fibrosis degrees of CHB patients. Thus, the use of markers obtained by Doppler US, especially PVF together with laboratory markers can provide significant contributions. Further studies with a high number of patients evaluating both laboratory and imaging markers together will be important in terms of elucidating this situation.

\section{Study Limitations}

Our study also had certain limitations: first, the number of patients was relatively small, and second, all measurements were undertaken by a single person only once. Therefore, we did not evaluate intraobserver and interobserver agreement. Considering the user-dependent nature of this process, it is inevitable that there would differences between the measurements of different radiologists, and even between those performed by the same radiologist at different times.

\section{Conclusion}

There is a consistent and growing need for easily reproducible tests for the effective diagnosis of significant hepatic fibrosis. Studies comparing the efficacy of liver biopsy and non-invasive tests guide the development and implementation of new techniques. This study concludes that Doppler US can help identify $\mathrm{CHB}$ patients with significant fibrosis.

\section{Ethics}

Ethics committee approval: This study was conducted with the approval of the Clinical Research Ethics Committee of our university (approval number: 9/15, date: 18.06.2020).

Informed Consent: All patients provided written informed consent.

Peer-review: Externally peer-reviewed.

\section{Authorship Contributions}

Surgical and Medical Practices: U.K., S..Ö.D., T.P., Concept: U.K., Ş.Ö.D., T.P., Design: U.K., Ş.Ö.D., T.P., Data Collection or Processing: U.K., Ş.Ö.D., T.P., Analysis or Interpretation: U.K., Ş.Ö.D., T.P., Literature Search: U.K., Ş.Ö.D., T.P., Writing: U.K., S..̈.D., T.P.

Conflict of Interest: The authors declare no conflict of interest.

Financial Disclosure: The authors declare that this study has not received any financial support.

\section{References}

1. Chrysanthos NV, Papatheodoridis GV, Savvas S, Kafiri G, Petraki K, Manesis EK, Archimandritis AJ. Aspartate aminotransferase to platelet ratio index for fibrosis evaluation in chronic viral hepatitis. Eur J Gastroenterol Hepatol 2006;18:389-396.
2. Lackner C, Struber G, Liegl B, Leibl S, Ofner P, Bankuti C, Bauer $B$, Stauber RE. Comparison and validation of simple noninvasive tests for prediction of fibrosis in chronic hepatitis C. Hepatology 2005:41:1376-1382.

3. Sterling RK, Lissen E, Clumerk N, Sola R, Correa MC, Montaner J, S Sulkowski M, Torriani FJ, Dieterich DT, Thomas DL, Messinger D, Nelson M; APRICOT Clinical Investigators. Development of a simple noninvasive index to predict significant fibrosis in patients with HIV/HCV coinfection. Hepatology 2006; 43: 1317-1325.

4. Poynard T, Bedossa P. Age and platelet count: A simple index for predicting the presence of histological lesions in patients with antibodies to hepatitis C virus. Metavir and Clinivir Cooperative Study Groups. J Viral Hepat 1997;4:199-208.

5. Myers RP, De Torres M, Imbert-Bismut F, Ratziu $V$, Charlotte F, Poynard T; MULTIVIRC Group. Biochemical markers of fibrosis in patients with chronic hepatitis $\mathrm{C}$ : a comparison with prothrombin time, platelet count, and age-platelet index. Dig Dis Sci 2003;48:146-153.

6. Güzelbulut F, Sezikli M, Akkan-Çetinkaya Z, Yașar B, Özkara S, Kurdaş-Övünç AO. AST-platelet ratio index in the prediction of significant fibrosis and cirrhosis in patients with chronic hepatitis B. Turk J Gastroenterol 2012;23:353-358.

7. Patriquin $\mathrm{H}$, Lafortune $\mathrm{M}$, Burns $\mathrm{PN}$, Dauzat M. Duplex Doppler examination in portal hypertension: technique and anatomy. AJR Am J Roentgenol 1987;149:71-76.

8. Gill RW. Measurement of blood flow by ultrasound accuracy and sources of error. Ultrasound in Med and Biol 1985;11:625-641.

9. McMahon BJ. Epidemiology and natural history of hepatitis B. Semin Liver Dis 2005;25:3-8.

10. Shindo M, Hamada K, Nishioji K, Muramatsu A, Oda Y, Okuno $\mathrm{T}$. The predictive value of liver fibrosis in determining the effectiveness of interferon and lamivudine therapies for chronic hepatitis B J Gastroenterol 2004;39 260-267.

11. Pinzani M, Vizzutti F, Arena $U$, Marra F. Technology insight: noninvasive assessment of liver fibrosis by biochemical scores and elastography. Nat Clin Pract Gastroenterol Hepatol 2008;5:95106

12. Manning DS, Afdhal NH. Diagnosis and quantitation of fibrosis. Gastroenterology 2008;134:1670-1681.

13. Castera L. Transient elastography and other noninvasive tests to assess hepatic fibrosis in patients with viral hepatitis. J Viral Hepat 2009;16:300-314

14. Lok ASF, McMahon BJ, Practice Guidelines Committee, American Association for the Study of Liver Diseases. Chronic hepatitis B: update of recommendations. Hepatology 2004;39:857-861.

15. Rocha HL, Diniz AL, Borges VF, Salomão FC. Assessment of portal venous index as a non-invasive method for diagnosing liver fibrosis in patients with chronic hepatitis C. Arq Gastroenterol 2012;49:14-18.

16. Friedman SL. Evaluation of fibrosis and hepatitis C. Am J Med 1999;107:27-30.

17. Myers RP. Noninvasive markers of liver fibrosis: playing the probabilities. Liver Int 2008;28:1328-31.

18. Walsh KM, Leen E, Mclver MacSween RN, Morris AJ. Hepatic blood flow changes in chronic hepatitis $\mathrm{C}$ measured by duplex Doppler color sonography: relationship to histological features. Dig Dis Sci 1998;43:2584-2590.

19. Oberti $F$, Valsesia E, Pilette $C$, Rousselet MC, Bedossa $P_{t}$ Aubé C, Gallois Y, Rifflet H, Maïga MY, Penneau-Fontbonne D, Calès P. Noninvasive diagnosis of hepatic fibrosis or cirrhosis. Gastroenterology 1997;113:1609-1616.

20. Cioni G, D'Alimonte P, Cristani A, Ventura P, Abbati G, Tincani E, Romagnoli R, Ventura E. Duplex-Doppler assessment of cirrhosis in patients with chronic compensated liver disease. J Gastroenterol Hepatol 1992;7:382-384. 
21. Colli A, Cocciolo M, Numoli N, Cattalini N, Fraquelli M, Conte D. Hepatic artery resistance in alcoholic liver disease. Hepatology 1999;28:1182-1186.

22. Aubé C, Oberti F, Korali N, Namour MA, Loisel D, Tanguy JY, Valsesia E, Pilette C, Rousselet MC, Bedossa P, Rifflet H, Maïga MY, Penneau-Fontbonne D, Caron C, Calès P. Ultrasonographic diagnosis of hepatic fibrosis or cirrhosis. J Hepatol 1999;30:472478.

23. Koda M, Murawaki Y, Kawasaki H, Ikawa S. Portal blood velocity and portal blood flow in patients with chronic viral hepatitis: relation to histological liver fibrosis. Hepatogastroenterology 1996;43:199-202.

24. Bernatik T, Strobel D, Hahn EG, Becker D. Doppler measurements: a surrogate marker of liver fibrosis? Eur J Gastroenterol Hepatol 2002; 14:383-387.

25. Lim AK, Patel N, Eckersley RJ, Kuo YT, Goldin RD, Thomas HC, Cosgrove DO, Taylor-Robinson SD, Blomley MJ. Can Doppler sonography grade the severity of hepatitis C-related liver disease? Am J Roentgenol 2005;184:1848-1853.
26. Su ZZ, Shan H, Ke WM, He BJ, Zheng RO. Portalsystemic hemodynamic changes in chronic severe hepatitis $B$ : an ultrasonographic study. World J Gastroenterol 2008;14:795-799.

27. Borges VFA, Diniz ALD, Cotrim HP, Rocha HLOG, Salomão FC. Hepatic vein Doppler flowmetry in patients with nonalcoholic steatosis. Radiol Bras 2011;44:1-6.

28. Colli A, Cocciolo M, Riva C, Martinez E, Prisco A, Pirola M, Bratina G. Abnormalities of Doppler waveform of the hepatic veins in patients with chronic liver disease: correlation with histologic findings. Am J Roentgenol 1994;162:833-837.

29. Iliopoulos P, Vlychou M, Margaritis V, Tsamis I, Tepetes K, Petsas T, Karatza C. Gray and color Doppler ultrasonography in differentiation between chronic viral hepatitis and compensated early stage cirrhosis. J Gastrointestin Liver Dis 2007;16:279-286.

30. Zheng RQ, Wang QH, Lu MD, Xie SB, Ren J, Su ZZ, Cai YK, Yao JL. Liver fibrosis in chronic viral hepatitis: an ultrasonographic study. World J Gastroenterol 2003;9:2484-2489. 